\title{
ANALISIS TEKNO EKONOMI PEMANFAATAN LIMBAH TUNA BERBASIS EKONOMI BIRU DI KOTA JAYA PURA
}

\section{Techno-Economic Analysis of Blue Economy-Based Tuna Waste Utilization in Jayapura City}

\author{
Halomoan Hutajulu ${ }^{1}$ Peggy Ratna Marlianingrum ${ }^{2 *}$, Albertina Nasri Lobo ${ }^{3}$, \\ Kristina Haryati ${ }^{4}$ \\ 1,3,4 Universitas Cenderawasih, halomoan.h@gmail.com; albertinanasrilobo@yahoo.co.id; \\ kristina.haryati.h@gmail.com \\ ${ }^{2}$ STIE Muhammadiyah Jakarta, peggyratna@ymail.com (Corresponding Author)
}

\begin{abstract}
ABSTRAK
Kota Jayapura sebagai wilayah pesisir, memiliki keunggulan sebagai daerah penghasil ikan tuna sirip kuning terbesar di Provinsi Papua. Kondisi pengelolaannya menggunakan model ekonomi linier berbasis output dan tidak berkelanjutan. Hal tersebut harus cepat diatasi, karena berdampak terhadap keberlanjutan pangan, penurunan stok ikan, pertumbuhan ekonomi terganggu. Berdasarkan keprihatinan tersebut, maka muncul model pengelolaan perikanan tuna sirip kuning yang berkelanjutan berbasis ekonomi biru. Tujuan penelitian: analisis tekno ekonomi pemanfaatan limbah ikan tuna sirip kuning menjadi pakan ikan organik. Responden penelitian yaitu sebanyak $45 \mathrm{KK}$ yang terdiri dari $35 \mathrm{KK}$ untuk sampel nelayan dengan menggunakan metode acak distratifikasi (stratified random sampling), dan $10 \mathrm{KK}$ responden untuk analisis tekno ekonomi pemanfaatan limbah ikan tuan sirip kuning menjadi pakan ikan organik. Jenis data yang digunakan berupa data primer dan sekunder. Metode analisis data yang digunakan yaitu: Analisis Harga Pokok Produksi, BEP, Variabel Costing. Hasil analisis menunjukkan bahwa analisis tekno ekonomi pemanfaatan limbah ikan cakalang layak dibuat menjadi pakan ikan organik, dengan cara pengolahan limbah ikan menjadi pakan. Hasil pembuatan pakan menghasilkan keuntungan yang sangat besar yang dapat menjadi sumber mata pencaharian alternatif bagi masyarakat, sekaligus dapat menjadikan ekosistem dan sumberdaya tetap lestari, juga dapat mengoptimalkan pemanfaatannya untuk peningkatan kesejahteraan masyarakat. Pengelolaan limbah ikan tuna sirip kuning juga dapat dikembangkan menjadi Usaha Mikro, Kecil dan Menengah (UMKM) yang berbasis ekonomi biru. Pemerintah Kota Jayapura dapat merekomendasikan strategi dan model pengelolaan perikanan tuna sirip kuning yang mencerminkan aspek menyeluruh dan terintegrasi antar sektor dalam mendukung pembangunan daerah Kota Jayapura yang efisien dan berkelanjutan.
\end{abstract}

Kata Kunci : Ikan Tuna Sirip Kuning, Kesejahteraan Masyarakat, Pengelolaan, Pemanfaatan, Perikanan berkelanjutan, Manfaat Ekonomi.

\begin{abstract}
Jayapura City as a coastal area, has the advantage of being the largest yellowfin tuna producer in Papua Province. The management condition uses a linear economic model based on output and is not sustainable. This must be resolved quickly, because it has an impact on food sustainability, decreasing fish stocks, and disrupting economic growth. Based on these concerns, a sustainable management model for yellowfin tuna based on the blue economy has emerged. The research objective: techno-economic analysis of the utilization of yellowfin tuna waste into organic fish feed. Respondents of the study were 45 households consisting of 35 households for fishermen
\end{abstract}


samples using stratified random sampling, and 10 respondents for techno-economic analysis of the use of yellow fin fish waste into organic fish feed. The types of data used are primary and secondary data. The data analysis methods used are: Cost of Production Analysis, BEP, Variable Costing. The results of the analysis show that the techno-economic analysis of skipjack tuna waste is feasible to be made into organic fish feed, by processing the fish waste into feed. The results of the manufacture of feed generate huge profits which can be an alternative source of livelihood for the community, as well as make the ecosystem and resources sustainable, as well as optimize its use for improving the welfare of the community. Yellowfin tuna waste management can also be developed into micro, small and medium enterprises (MSMEs) based on the blue economy. The Jayapura City Government can recommend a yellowfin tuna fisheries management strategy and model that reflects a comprehensive and integrated aspect between sectors in supporting the efficient and sustainable regional development of Jayapura City

Keywords : Yellowfin Tuna, Community Welfare, Management, Utilization, Sustainable Fisheries, Economic Benefits.

Naskah diterima : 19-03-2021, Naskah dipublikasikan : 31-03-2021

\section{PENDAHULUAN}

Pakan dalam kegiatan budidaya perikanan mempunyai peran sangat penting, dimana dari keseluruhan biaya produksi sekitar 60\% -80\% adalah untuk penyediaan pakan (Sahwan 2003; Dewi dan Tahapari 2017. Pakan ikan mutlak dibutuhkan untuk memenuhi kebutuhan nutrisi ikan yang dibudidayakan. Kualitas pakan ikan sangat dipengaruhi oleh bahan penyusun pakan dimana harus memenuhi kebutuhan nutrisi ikan (protein, lemak, karbohidrat, vitamin dan mineral) budidaya. Kebutuhan nutrisi dalam pakan sangat dipengaruhi oleh umur dan ukuran serta jenis ikan yang dibudidayakan. Oleh sebab itu ketersediaan pakan yang lengkap nutrisinya sangat penting guna mendukung pertumbuhan dan kelangsungan hidup ikan budidaya. Pakan (pellet) ikan yang lengkap nutrisinya harganya cukup mahal. Hal ini disebabkan karena bahan baku tepung ikan sebagian besar masih diimpor dan setiap saat harganya naik sehingga harga pakan ikan ikut naik. Hal ini sangat memberatkan pembudidaya ikan. Oleh sebab itu perlu dicari alternatif bahan baku pakan yang mudah dan murah namun kualitasnya dapat menggantikan tepung ikan dalam pakan.

Limbah ikan yaitu kepala, isi perut dan tulang ikan di PPI Hamadi selama ini hanya dibuang dan tidak dikelola dengan baik. Aktifitas pendaratan dan penjualan ikan setiap hari menghasilkan limbah ikan yang tidak sedikit walaupun pada musim tertentu pada saat hasil tangkapan kurang limbah kepala ikan dan tulang tetap dijual. Limbah ikan yang dihasilkan setiap hari memberikan dampak buruk terhadap lingkungan terutama lingkungan perairan laut disekitar PPI Hamadi karena limbah langsung dibuang ke laut. Limbah ikan ini dapat dimanfaatkan untuk diolah menjadi tepung ikan sebagai salah satu alternatif bahan baku pakan ikan. Penelitian pemanfaatan limbah ikan sebagai campuran pakan berbagai jenis ternak dan ikan menunjukkan hal positif dan dapat digunakan sebagai campuran bahan pakan ikan (Sihite, 2013; Fahrizal dan Ratna 2018; Ali dkk. 2018) Ketersediaan limbah ikan yang melimpah sangat prospek untuk diolah menjadi tepung sehingga dapat dimanfaatkan sebagai bahan campuran pakan ikan. Melalui pemanfaatan limbah ikan ini diharapkan dapat meminimalisir dampak buruk terhadap lingkungan sekaligus memberikan manfaat sebagai bahan baku pakan pengganti tepung ikan.

Tujuan kegiatan pengolahan limbah ikan menjadi pakan ikan adalah untuk mengetahui dan memanfaatkan bahan limbah ikan sebagai alternatif bahan baku pakan ikan (pellet). Sedangkan kegunaannya adalah membantu pembudidaya ikan dalam menekan biaya produksi budidaya ikan dengan menekan biaya pakan melalui pemanfaatan limbah ikan sehingga dapat meningkatkan 
pendapatan pembudidaya. Disamping itu dampak terhadap pencemaran lingkungan perairan dapat diminimalisir.

Alat dan bahan yang digunakan pada kegiatan ini adalah sebagai berikut:

Tabel 1. Alat dan bahan yang digunakan pada kegiatan pembuatan pakan ikan

\begin{tabular}{|c|c|c|}
\hline No & Nama Alat/Bahan & Kegunaan \\
\hline 1 & Alat: & \\
\hline & a. Timbangan & Untuk menimbang bahan-bahan \\
\hline & b. Keranjang & Menampung limbah dan meniriskan \\
\hline & c. Baskom besar & Tempat mencampur bahan \\
\hline & d. Ember besar & Menampung bahan pasta \\
\hline & e. Dandang & Untuk merebus limbah ikan \\
\hline & f. Tungku/Kompor & Sumber panas untuk merebus limbah ikan \\
\hline & g. Timba & Mencuci limbah dan peralatan \\
\hline & h. Baskom kecil & Tempat menampung bahan baku pellet \\
\hline & i. Gilingan Daging & Menggiling limbah ikan dan mencetak pellet \\
\hline & j. Mesin Penepung & Menghaluskan limbah ikan yang kering \\
\hline & k. Mesin cetak Pellet & Mencetak bahan menjadi pellet \\
\hline & 1. Niru & Wadah untuk menjemur pellet hasil cetakan \\
\hline & m. Oven & Mengeringkan pellet \\
\hline \multirow[t]{8}{*}{2} & Bahan: & \\
\hline & a. Limbah ikan & Sumber bahan tepung ikan \\
\hline & b. Dedak & Bahan baku campuran pakan ikan \\
\hline & c. Ampas Tahu & Bahan baku campuran pakan ikan \\
\hline & d. Pig Mix & Sumber mineral dalam pakan \\
\hline & e. Vitaciks & Sumber vitamin dalam pakan \\
\hline & f. Minyak sayur & Sumber lemak dalam pakan \\
\hline & g. Tepung Tapioka & Sebagai perekat pakan ikan \\
\hline
\end{tabular}

Sumber : Data Primer (2020)

\section{KAJIAN LITERATUR \\ Perikanan Tangkap}

Pauly dan Watson (2005) mendefinisikan perikanan adalah kegiatan eksploitasi sumberdaya hayati dari laut. Widodo dan Suadi (2006) tujuan pengelolaan sumberdaya perikanan terdiri dari: biologi, ekologi, ekonomi dan sosial, dimana tujuan sosial mencakup tujuan politik dan budaya.

\section{Pendapatan Nelayan}

Pendapatan adalah jumlah penghasilan yang diterima oleh penduduk atas prestsi kerjanya selama satu periode tertentu, baik harian, mingguan, bulanan ataupun tahunan (Sukirno, 2006: 139). Pendapatan nelayan adalah selisih antara penerimaan (TR) dan biaya operasional yang digunakan (TC). Biaya tetap (FC) adalah biaya yang harus dikeluarkan persatuan waktu tertentu, untuk keperluan semua input tetap, dan jumlahnya tidak bergantung dari banyaknya hasil tangkapan yang diperoleh. Biaya variabel (VC) biaya yang harus dikeluarkan pada waktu tertentu, untuk pembayaran semua input variabel yang digunakan dalam proses penangkapan ikan. Total biaya (TC) adalah jumlah dari biaya tetap (FC) ditambah biaya variabel (VC) (Pratama \& Manurung, 2010).

Pendapatan nelayan berasal dari dua sumber, yaitu: pendapatan dari usaha penangkapan ikan dan pendapatan dari luar usaha penangkapan ikan. Sujarno (2008:38) terdapat beberapa faktor yang mempengaruhi pendapatan nelayan yaitu: a) pengalaman nelayan, b) musim, c) teknologi, d) bahan 
bakar minyak (BBM). Dahuri (2004) upaya untuk memahami tingkat pendapatan nelayan dari hasil produksi ikan nelayan per hari. Bila pendapatan suatu daerah relatif rendah, dapat dikatakan bahwa kemajuan dan kesejahteraan tersebut akan rendah pula. Kelebihan dari konsumsi dapat disimpan di bank dengan tujuan berjaga-jaga, demikian pula bila pendapatan masyarakat suatu daerah relatif tinggi, maka tingkat kesejahteraan dan kemajuan daerah tersebut tinggi pula (Danil, 2013).

\section{Teori Nelayan}

Imron (2003) menyatakan nelayan adalah sekelompok masyarakat yang kehidupannya tergantung pada hasil tangkapan dan budidaya laut. Mereka pada umumnya tinggal di pinggir pantai, sebuah pemukiman dekat dengan lokasi kegiatannya. Nelayan adalah orang yang mata pencahariannya melakukan penangkapan ikan (UU Nomor 45 Tahun 2009).

Nelayan adalah masyarakat yang hidup, tumbuh, berkembang di kawasan pesisir, yakni suatu kawasan transisi antara wilayah darat dan laut (Kusnadi, 2009). Kehidupan nelayan tergantung hasil laut (Helmi, 2012). Nelayan sering terisolasi karena mereka harus tinggal di sepanjang pinggiran danau, sungai, atau laut (Manurung et al, 2014).

\section{Ekonomi Biru}

Ekonomi biru adalah paradigma pembangunan ekonomi yang berazaskan pada prinsipprinsip ekosistem dan akan mampu menghasilkan pertumbuhan (Pauli 2010). Konteks wilayah pesisir dan laut, ekonomi biru adalah aktivitas ekonomi pemanfaatan sumberdaya alam dan jasa ekosistemnya yang didukung aktivitas ekonomi daratan serta memberikan kemakmuran bagi masyarakat secara berkelanjutan (Kusumastanto 2012).

Langkah-langkah utama pembangunan bidang perikanan sebagai bagian dari program revitalisasi ekonomi nasional dalam mewujudkan ekonomi biru sektor perikanan menurut DEKIN (Dewan Kelautan Indonesia) (2012) yaitu:

1) Mengoptimalkan dan memperkuat usaha dan industri perikanan tangkap yang efisien, produktif, ramah lingkungan, dan sesuai dengan standar internasional,

2) Mengoptimalkan dan memperkuat usaha dan industri perikanan budidaya yang efisien, produktif, ramah lingkungan, inovatif, dan sesuai standar internasional,

3) Mengembangkan dan memperkuat usaha, industri pengolahan hasil perikanan yang efisien, nir-limbah dan terpadu dengan perikanan tangkap dan budidaya,

4) Mengembangkan sistem pemasaran dan manajemen usaha perikanan yang transparan, adil, dan menguntungkan semua pihak,

5) Mengembangkan dan memperkuat usaha, industri pengolahan hasil laut non-ikan yang efisien, nir-limbah, inovatif, kreatif, dan terpadu dengan sentra-sentra produksi..

\section{Limbah Ikan}

Limbah ikan dapat berupa jenis-jenis ikan yang rusak fisiknya, tidak bernilai ekonomis, sisasisa olahan ikan, insang, perut ikan, dan sirip serta ikan dengan tingkat kesegaran yang tidak layak digunakan sebagai bahan pangan bagi manusia. Limbah ikan tersebut masih mengandung nutrien organik berada dalam badan air akan menyebabkan eutrofikasi pada perairan umum, yang kemudian akan menyebabkan kematian organisme yang hidup dalam air tersebut, pendangkalan, penyuburan ganggang dan bau-bau yang tidak nyaman (Edison, 2015)

\section{METODOLOGI PENELITIAN}

Penelitian ini dilaksanakan di Kelurahan Hamadi dan Dok 9 Kota Jayapura yang dilaksanakan mulai bulan Mei-Juli 2020. Penelitian dilaksanakan di Kota Jayapura yang meliputi 2 (dua) kelurahan yaitu: Kelurahan Hamadi, dan Kelurahan Dok 9 merupakan kelurahan yang 
sangat strategis untuk pengembangan perikanan dalam rangka meningkatkan kesejahteraan masyarakat nelayan dan juga dapat mendukung pertumbuhan ekonomi wilayah Kota Jayapura.

Populasi penelitian adalah masyarakat nelayan yang tinggal di 2 kelurahan yaitu: Kelurahan Hamadi dan Kelurahan Dok 9 yaitu sebanyak 350 KK (BPS Kota Jayapura, 2018). Metode penarikan sampel dengan menggunakan metode acak distratifikasi (stratified random sampling) yaitu:

1. Melakukan stratifikasi dan memilih langsung penduduk yang berprofesi sebagai nelayan perikanan tuna sirip kuning. Sampel akan diwawancarai di beberapa tempat yaitu: di PPI Kelurahan Hamadi, dan PPI Dok 9.

2. Stratifikasi nelayan tangkap ikan tuna sirip kuning

3. Jumlah sampel penelitian yaitu sebanyak $10 \%$ dari total nelayan perikanan tangkap sebanyak $350 \mathrm{KK}$ atau sebanyak $35 \mathrm{KK}$. Informasi lebih lengkap tentang jumlah responden dijelaskan dalam tabel berikut ini:

Tabel 2. Pembagian responden penelitian

\begin{tabular}{|c|l|c|c|}
\hline No & \multicolumn{1}{|c|}{ Tujuan Penelitian } & $\begin{array}{c}\text { Populasi } \\
\text { (KK) }\end{array}$ & $\begin{array}{c}\text { Sampel } \\
(\text { KK) }\end{array}$ \\
\hline 1 & $\begin{array}{l}\text { Nilai manfaat ikan tuna sirip kuning terhadap } \\
\text { kesejahteraan nelayan dan evaluasi manajemen } \\
\text { pengelolaan tuna sirip kuning }\end{array}$ & 350 & 35 \\
\hline 2 & $\begin{array}{l}\text { Analisis tekno ekonomi pemanfaatan limbah ikan tuna } \\
\text { sirip kuning menjadi pakan ikan organik }\end{array}$ & 15 & 10 \\
\hline \multicolumn{1}{|c|}{ Jumlah } & $\mathbf{4 5}$ \\
\hline
\end{tabular}

Jenis Data yang digunakan data primer yang diperoleh melalui kuesioner meliputi data: jumlah ikan hasil tangkapan, jumlah pendapatan, nilai manfaat jasa ekosistem laut, manajemen pengelolaan dan pemanfaatan perikanan di Kota Jayapura, strategi pemanfaatan perikanan tuna sirip kuning, limbah ikan tuna sirip kuning di setiap PPI dan nelayan. Data sekunder dapat diperoleh dari instansi terkait dan hasil publikasi yakni: Data produksi perikanan tangkap pelagis besar (tuna sirip kuning), nilai ekonomi, dokumen perencanaan pengelolaan wilayah, pesisir dan perikanan tangkap, jasa ekosistem, data sosial budaya masyarakat nelayan, data potensi dan riil sumberdaya alam termasuk data perikanan Kota Jayapura. Sumber data diperoleh dari berbagai instansi pemerintah yaitu meliputi: Bappeda Kota Jayapura, Dinas Kelautan dan Perikanan Kota Jayapura dan Provinsi Papua, BPS Kota Jayapura, Masyarakat nelayan lokal, dan pengusaha perikanan. Metode pengumpulan data yang digunakan adalah survey lapangan, dengan menggunakan sistem pengamatan langsung, wawancara, dan FGD (Focus Group Dicusion) dengan para tokoh masyarakat, para nelayan, dan seluruh pelaku ekonomi (pemerintah, swasta dan masyarakat) yang terdapat di Kota Jayapura. Tahapan proses pembuatan pemanfaatan limbah ikan menjadi pakan ikan yaitu: 


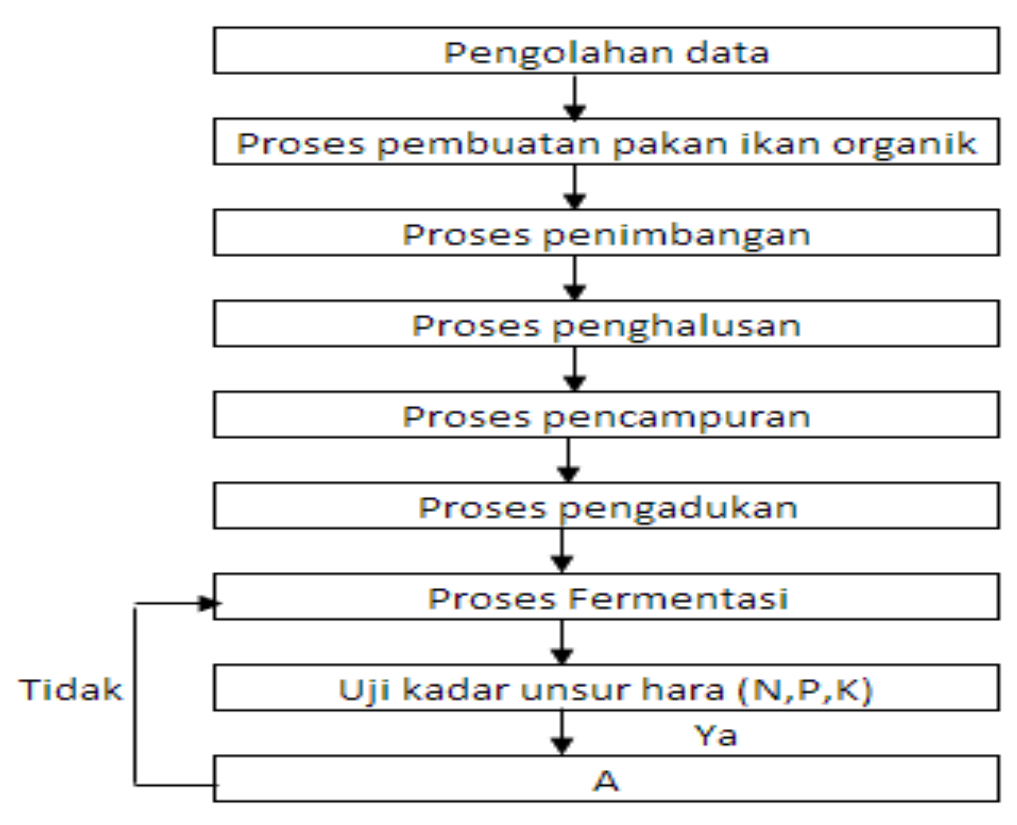

Gambar 1. Tahapan proses pembuatan pemanfaatan limbah ikan menjadi pakan ikan

Bahan yang digunakan: kuesioner, catatan harian (logbook), peta wilayah, alat yang digunakan adalah : kamera, alat perekam, dan peralatan lapangan lainnya. Metode Analisis Data Analisis Harga Pokok Produksi/HPP, BEP (Break Even Point), Variabel Costing yaitu meliputi:

I. Pembuatan Tepung Ikan

1. Limbah ikan (Kepala, isi perut, tulang dan sirip) dikumpulkan dari PPI Hamadi, selanjutnya dicuci bersih untuk membuang darah dan kotoran lainnya.

2. Selanjutnya ditiriskan untuk membuang air yang berlebih.

3. Proses selanjutnya adalah perebusan dalam wadah yang besar (Panci/drum) sampai mendidih dan limbah ikan diangkat dan ditiriskan.

4. Setelah kadar air berkurang langkah selanjutnya adalah digiling dengan mesin gilingan daging Hasil gilingan berupa pasta yang dapat langsung dicampur dengan bahan lain untuk membuat pellet ikan atau dijemur lagi sampai kering agar dapat disimpan.

5. Apabila hasil gilingan (pasta) akan disimpan maka pasta langsung dijemur sampai kering atau dioven apabila cuaca mendung untuk menghindari pasta limbah ikan membusuk.

6. Pasta yang telah kering sudah menjadi tepung ikan dapat disimpan dan digunakan sebagai bahan baku pakan ikan. Hasil proses pengolahan limbah ikan ini diperoleh bobot kering sekitar 40 persen dari bobot basah limbah.

II. Pembuatan pellet ikan

Pembuatan pakan ikan dengan menggunakan limbah ikan yang telah diolah menjadi pasta dan tepung dapat dilakukan dengan dua cara yaitu:

1. Pembuatan pellet dengan bahan pasta limbah ikan dimana langsung dicampur dengan bahan baku lainnya sesaat setelah proses penggilingan (setelah diketahui persentase penyusutan pasta ikan setelah dikeringkan)

a. Bahan limbah ikan telah digiling menjadi pasta maka proses pembuatan pakan bisa dilakukan dengan menentukan komposisi bahan-bahan pembuat pellet ikan dengan 
menggunakan Least Cost Formulation pada Microsoft Exel. Jumlah bahan pasta limbah dikonversi dengan persentase 40 persen dari bobot basah bahan limbah ikan.

b. Selanjutnya masing masing bahan baku ditimbang sesuai persentase bahan dalam pellet ikan dengan kadar protein yang telah ditentukan.

c. Bahan baku campuran pakan ikan lainnya komposisi nutrisinya didasarkan pada komposisi umum berdasarkan literatur dan SNI Pakan.

d. Mencampur bahan dalam wadah dengan dimulai dari jumlah bahan yang sedikit sampai yang banyak persentasenya.

e. Mencetak bahan yang telah dicampur dengan mesin pellet selanjutnya dikeringkan dengan sinar matahari atau dioven.

2. Pembuatan pellet dengan bahan tepung ikan limbah yang telah digiling dan dikeringkan.

a. Pasta limbah ikan yang telah dikeringkan dan digiling menjadi tepung maka sampel diuji proksimat untuk mengetahui kandungan nutrisinya (protein, lemak, karbohidrat, abu). Hal ini penting sebagai dasar dalam membuat formulasi pakan.

b. proses pembuatan pakan dilakukan dengan menentukan komposisi bahan-bahan pembuat pellet ikan dengan menggunakan Least Cost Formulation pada Microsoft Exel.

c. Selanjutnya masing masing bahan baku ditimbang sesuai persentase bahan dalam pellet ikan dengan kadar protein yang ditentukan (30\%)

d. Mencampur bahan dalam wadah dengan dimulai dari jumlah bahan yang sedikit sampai yang banyak persentasenya.

e. Mencetak bahan yang telah dicampur dengan mesin pellet selanjutnya dikeringkan dengan sinar matahari 2-3 hari atau dioven.

f. Pellet ikan siap diberikan ke ikan dan atau disimpan dalam wadah kedap udara.

g. Guna mengetahui komposisi nutrisi Pellet dengan bahan limbah ikan, selanjutnya diuji proksimat untuk mengetahui komposisi nutrisinya.

\section{HASIL DAN PEMBAHASAN}

\section{Pengolahan Limbah Ikan Menjadi Tepung Ikan}

Pengolahan limbah ikan menjadi tepung ikan dimulai dengan pengumpulan, pencucian dan penirisan, perebusan, penggilingan, dan penepungan. Penentuan hasil pengolahan menjadi tepung diperoleh hasil $40 \%$ dari berat basah bahan limbah ikan. Artinya dengan bahan limbah ikan 1 kilogram dapat diperoleh tepung ikan sebesar 400 gram. Tepung ikan yang telah kering dilanjutkan dengan uji proksimat pada Laboratorium Kimia Fakultas MIPA Universitas Cenderawasih. (Tabel 3).

Tabel 3. Nilai Proksimat dari Tepung bebahan Limbah Ikan Tuna/Cakalang

\begin{tabular}{lcc}
\hline \multicolumn{1}{c}{ Nilai (\%) } & Tepung Limbah Ikan* & SNI (2006)** \\
\hline Air & - & maks. 12 \\
Protein & - & min. 30 \\
Lemak & - & maks. 5 \\
Karbohidrat & - & 6 \\
Abu & - & 13 \\
\hline
\end{tabular}

Sumber: Data primer diolah, 2020

Keterangan:

*: Uji Proksimat dari Laboratorium Kimia Fak MIPA UNCEN

**: Standar SNI bahan baku pakan 
Hasil uji proksimat menunjukkan bahwa nilai air dan karbohidrat tepung ikan menurut SNI masing-masing sebesar maksimal 12 dan sebesar 6. Temuan Fahrizal dan Ratna (2018) menyatakan bahwa hasil uji proksimat tepung berbahan limbah ikan berdasarkan jenis ikan tuna, cakalang, teri dan sarden layak untuk digunakan sebagai bahan pembuatan pellet ikan.

\section{Pembuatan Pellet ikan}

Hasil formulasi pakan dengan bahan baku tepung limbah ikan yang diformulasikan dengan bahan lain (dedak dan ampas tahu) dapat dilihat pada Tabel 4.

Tabel 4. Persentase jumlah bahan pada formulasi pakan ikan dengan bahan baku limbah ikan

\begin{tabular}{|l|r|r|}
\hline \multicolumn{1}{|c|}{ dengan bahan baku limbah ikan } \\
\hline Bahan & Persentase (\%) & Jumlah (1000 gram) \\
\hline Tepung limbah ikan & $40 \%$ & 400 \\
\hline Dedak & $26 \%$ & 260 \\
\hline Mineral & $26 \%$ & 260 \\
\hline Vitamin & $1 \%$ & 10 \\
\hline Tepung tapioca & $1 \%$ & 10 \\
\hline & $6 \%$ & 60 \\
\hline
\end{tabular}

Sumber: data primer diolah, 2020.

Tabel di atas menjelaskan bahwa komposisi pembuatan pakan ikan porsi terbanyak adalah tepung limbah ikan sebanyak $40 \%$ atau 400 gram diikuti dedak dan dedak jagung masing-masing sebesar 26\%, serta penggunaan tepung tapioka mencapai 6\%. Temuan Apu (2017) menyatakan pengolahan jeroan ikan cakalang terbaik dengan metode langsung dibandingkan dengan metode pengukusan dan perebutsan, dosis tepung jeroan ikan cakalang mampu mensubstitusi tepung ikan sebesar $50 \%$ pada pakan buatan ikan nila. 


\section{JURNAL EKOBIS: EKONOMI, BISNIS \& MANAJEMEN}

\section{Vol 11 Nomor 1 (2021)}

Tabel 5. Komposisi pakan (\%)

\begin{tabular}{|c|c|c|c|c|c|c|c|c|c|c|c|c|c|c|c|c|c|c|c|c|}
\hline $\begin{array}{l}\text { Bahan } \\
\text { baku }\end{array}$ & Air & $\begin{array}{l}\text { Pro- } \\
\text { tein }\end{array}$ & Lipid & Serat & Abu & NFE & $\mathbf{C a}$ & $\mathbf{P}$ & $\begin{array}{l}\text { Kom- } \\
\text { posisi }\end{array}$ & Air & $\begin{array}{l}\text { Pro- } \\
\text { tein }\end{array}$ & Lipid & Serat & $\mathbf{A b u}$ & NFE & $\mathbf{C a}$ & $\mathbf{P}$ & Energi & $\begin{array}{l}\text { Harga } \\
\text { /kg }\end{array}$ & $\begin{array}{l}\text { Harga } \\
\text { /unit }\end{array}$ \\
\hline Tepung Ikan & 9.13 & 50.00 & 8.59 & 0.69 & 13.50 & 8.91 & 5.82 & 3.01 & 50.00 & 4.57 & 25.00 & 4.30 & 0.35 & 6.75 & 4.46 & 2.91 & 1.51 & 2.00 & 6,000 & 3,000 \\
\hline $\begin{array}{l}\text { Tepung } \\
\text { Kedelai }\end{array}$ & 10.86 & 41.65 & 3.65 & 2.72 & 5.64 & 35.58 & 0.29 & 0.68 & & - & - & - & - & - & - & - & - & - & & - \\
\hline MBM & 7.04 & 40.66 & 12.21 & 20.74 & 9.39 & 2.95 & 5.00 & - & & - & - & - & - & - & - & - & - & - & & - \\
\hline Dedak & 9.80 & 11.80 & 11.70 & 13.20 & 7.50 & 55.80 & 0.30 & 0.70 & 45.00 & 4.41 & 5.31 & 5.27 & 5.94 & 3.38 & 25.11 & 0.14 & 0.32 & 1.80 & 5,000 & 2,250 \\
\hline $\begin{array}{l}\text { AMPAS } \\
\text { TAHU }\end{array}$ & 9.83 & 24.00 & 15.89 & 12.38 & 4.44 & 40.68 & & & - & - & - & - & - & - & - & - & - & - & & - \\
\hline $\begin{array}{l}\text { Tepung } \\
\text { jagung }\end{array}$ & 12.34 & 8.42 & 3.71 & 1.97 & 1.37 & 59.60 & 0.06 & 0.21 & - & - & - & - & - & - & - & - & - & - & & - \\
\hline Tapioka & 9.00 & 1.00 & & & & 90.00 & & & 2.00 & 0.18 & 0.02 & - & - & - & 1.80 & - & - & 0.07 & 12,000 & 240 \\
\hline $\begin{array}{l}\text { Minyak } \\
\text { sayur }\end{array}$ & & & 100.00 & & & & & & 1.00 & - & - & 1.00 & - & - & - & - & - & 0.09 & & - \\
\hline minyak ikan & & & 100.00 & & & & & & - & - & - & - & - & - & - & - & - & - & & - \\
\hline $\begin{array}{l}\text { Crude Palm } \\
\text { Oil }\end{array}$ & & & 100.00 & & & & & & - & - & - & - & - & - & - & - & - & - & & - \\
\hline Premix & & & & & & & & & 1.00 & - & - & - & - & - & - & - & - & - & 40,000 & 400 \\
\hline Vitamin & & & & & & & & & 1.00 & - & - & - & - & - & - & - & - & - & 40,000 & 400 \\
\hline $\begin{array}{l}\alpha \text {-tocopherol } \\
\text { acetate }\end{array}$ & & & & & & & & & & - & - & - & - & - & - & - & - & - & & - \\
\hline $\mathrm{NaCl}$ & & & & & & & & & - & - & - & - & - & - & - & - & - & - & 5,000 & - \\
\hline Jumlah & & & & & & & & & 100.00 & 9.16 & 30.33 & 10.56 & 6.29 & 10.13 & 31.37 & 3.05 & 1.82 & 3.97 & & $6,290.00$ \\
\hline
\end{tabular}

Sumber: Hasil Penelitian, 2020 


\section{JURNAL EKOBIS: EKONOMI, BISNIS \& MANAJEMEN \\ Vol 11 Nomor 1 (2021)}

\section{Nilai Harga Pokok Produksi (HPP)}

Menghitung harga pokok produksi dengan menggunakan metode variable costing biaya yang dijadikan sebagai dasar penentuan biaya produksi adalah biaya bahan baku, biaya tenaga kerja, dan biaya overhead variable. Perhitungan jarak dilakukan dengan metode rectilinear distance.

Variabel costing adalah metode penentuan harga pokok produksi yang hanya memperhitungkan biaya produksi yang bersifat variable yaitu biaya bahan baku dan biaya tenaga kerja langsung.

a. Biaya bahan baku. Biaya bahan baku merupakan seluruh biaya yang dikeluarkan dalam proses pembuatan pakan ikan ini. Adapun rincian biayanya yaitu:

Tabel 6. Biaya bahan baku pembuatan pakan ikan

\begin{tabular}{|c|l|c|r|}
\hline No. & \multicolumn{1}{|c|}{ Keterangan } & Jumlah & Harga/Hari (Rp) \\
\hline 1 & Limbah ikan cakalang & $10 \mathrm{~kg}$ & 30.000 \\
\hline 2 & Pembelian dedak & $3 \mathrm{~kg}$ & 3.500 \\
\hline 3 & Dedak Jagung & $3 \mathrm{~kg}$ & 4.500 \\
\hline 4 & Mineral & $1 \mathrm{liter}$ & 7.500 \\
\hline 5 & Vitamin & $100 \mathrm{~g}$ & 15.000 \\
\hline 6 & Tepung tapioca & $1.5 \mathrm{~kg}$ & 7.000 \\
\hline \multicolumn{2}{|c|}{ Jumlah } & Rp.67.500 \\
\hline
\end{tabular}

Sumber: data primer diolah, 2020.

Jumlah biaya bahan baku sebesar Rp.67.500, dimana nantinya akan menghasilkan pakan ikan sebanyak $7.5 \mathrm{~kg}$, dengan demikian produksi satu tahun dana bahan baku yang diperlukan sebanyak Rp.15.000.000 dan akan menghasilkan pakan sebanyak $2.250 \mathrm{~kg}$. Biaya tenaga kerja dalam pembuatan pakan ikan organik sebanyak 1 orang pekerja dengan upah Rp.15.000/hari. Biaya overhead variabel adalar kulkas dan blender, air dan BBM. Berikut ini biaya perhitungan:

Tabel. 7. Biaya overhead variabel

\begin{tabular}{|c|l|c|r|}
\hline No. & Keterangan & Jumlah & \multicolumn{1}{|c|}{ Harga/Hari (Rp) } \\
\hline 1 & Listrik & 2 jam & 650 \\
\hline 2 & BBM & 1 liter & 6.500 \\
\hline 3 & Air & 1.5 liter & 6.000 \\
\hline \multicolumn{2}{|c|}{} & 13.500 \\
\hline
\end{tabular}

Sumber: data primer diolah, 2020.

Jumlah biaya overhead variable sebesar Rp.13.500 x 300 hari= Rp.4.050.000. Biaya overhead tetap. Biaya overhead tetap merupakan biaya dimana akan tetap terdapat merupakan biaya dimana akan tetap terdapat biaya walaupun tidak sedang terjadi aktivitas produksi, dalam penelitian ini yang termasuk kedalam biaya overhead tetap yakni seluruh biaya depreasiasi dari peralatan yang digunakan. Rincian biayanya yaitu:

Tabel 8. Biaya overhead tetap

\begin{tabular}{|r|l|r|r|r|r|}
\hline No. & \multicolumn{1}{|c|}{ Keterangan } & Jumlah & Harga (Rp) & \multicolumn{1}{|c|}{$\begin{array}{c}\text { Masa pakai } \\
\text { (tahun })\end{array}$} & \multicolumn{1}{c|}{$\begin{array}{c}\text { Depresiasi } \\
(\mathrm{Rp})\end{array}$} \\
\hline 1 & Blender & 1 & 450.000 & 3 & 150.000 \\
\hline 2 & $\begin{array}{l}\text { Alat penggiling } \\
\text { daging }\end{array}$ & 1 & 200.000 & 5 & 40.000 \\
\hline 3 & Baskom & 1 & 10.000 & 2 & 5.000 \\
\hline 4 & Panci & 1 & 25.000 & 2 & 12.500 \\
\hline 5 & Wajan & 1 & 35.000 & 2 & 17.500 \\
\hline 6 & Wadah talam & 1 & 100.000 & 2 & 50.000 \\
\hline 7 & Timbangan & 1 & 135.000 & 2 & 67.500 \\
\hline
\end{tabular}




\begin{tabular}{|c|c|c|r|r|r|}
\hline No. & Keterangan & Jumlah & Harga (Rp) & $\begin{array}{c}\text { Masa pakai } \\
\text { (tahun) }\end{array}$ & $\begin{array}{c}\text { Depresiasi } \\
(\mathrm{Rp})\end{array}$ \\
\hline 8 & Spatula & 1 & 6.000 & 2 & 3.000 \\
\hline \multicolumn{3}{|c|}{ Jumlah } & 13.500 & & 345.500 \\
\hline
\end{tabular}

Sumber: data primer diolah, 2020.

Harga pokok per kilogram pakan ikan:

Upaya memahami harga per kg pakan ikan dapat dihitung dengan total biaya variabel dibagi dengan total produk yang dihasilkan. Maka rincian penggolongan biaya sebelum dihitung HPP yaitu:

Tabel 9. Rincian penggolongan biaya sebelum analisis HPP

\begin{tabular}{|c|l|r|}
\hline No. & \multicolumn{1}{|c|}{ Jenis biaya } & \multicolumn{1}{c|}{ Biaya per tahun } \\
\hline \multicolumn{2}{|c|}{ Biaya variabel } & 15.000 .000 \\
\hline 1 & Bahan baku & 4.500 .000 \\
\hline 2 & Tenaga kerja & 4.050 .000 \\
\hline 3 & Overhead variabel & 23.550 .000 \\
\hline \multicolumn{2}{|c|}{ Total biaya variabel } \\
\hline \multicolumn{2}{|c|}{ Biaya tetap } \\
\hline $1 \quad$ Depresiasi & 312.167 \\
\hline \multicolumn{2}{|l|}{ Total } & 23.237 .833 \\
\hline
\end{tabular}

Sumber: data primer diolah, 2020.

Perhitungan harga pokok produksi per kg:

HPP per $\mathrm{kg}=$ Total Biaya/Jumlah yang diproduksi

$=$ Rp. $67.500 / 7.5 \mathrm{~kg}$

$=\mathrm{Rp} \cdot 9.000 / \mathrm{kg}$

Hasil perhitungan harga pokok produksi dengan biaya produksi sebesar Rp.11.000, maka didapatkan harga pokok produksi pakan ikan organik sebesar Rp.11.000/kg. Hasil tersebut menjadi harga pokok pakan ikan yang ditawarkan ke konsumen dengan keuntungan margin sebesar Rp. $20 \%$

Harga jual : Total biaya + Laba yang diharapkan / total produksi

: Rp. $67.500+(10 \%$ x Rp. 67.500$) / 7.5 \mathrm{~kg}$

:Rp. $67.500+$ Rp.6.750 kg/7.5

: Rp.74.250

: Rp.9.900/kg

Harga jual pakan ikan organik didapatkan sebesar Rp.9.900/kg, harga ini lebih murah dibandingkan dengan harga pakan ikan organik di pasaran Rp.11.000/kg.

\section{Break even point (BEP)}

Break even point (BEP) adalah kondisi dimana perusahaan tidak rugi dan tidak untung atau jumlah penghasilan sama dengan total biaya. Berikut ini nilai BEP:

BEP unit = Biaya tetap/harga jual per unit - variable per unit

$=$ Rp. $345.500 /$ Rp. $9.900-$ Rp. 9.000

$=$ Rp. $345.500 / \mathrm{Rp} .900$

$=383.89 \mathrm{~kg}$

Jumlah BEP unit pakan ikan sebesar Rp.383.89 kg, temuan Kusumanto \& Hidayat (2018) yaitu BEP unit sebesar Rp.2.280 kg di Kota Pekanbaru. Hal tersebut menunjukkan usaha pembuatan pakan akan menghasilkan untung. Oleh karena itu usaha ini perlu untuk dikembangkan pada masa yang akan datang, dalam rangka meningkatkan pendapatan keluarga $\mathrm{BEP}$ (rupiah) = Biaya tetap/1-biaya variable/penjualan 
Jumlah BEP unit pakan ikan sebesar Rp.34.550.000 kg, sementara temuan Kusumanto \& Hidayat (2018) yaitu BEP rupiah sebesar Rp.11.669.660 di Kota Pekan Baru. Hal tersebut menunjukkan usaha pembuatan pakan akan menghasilkan untung yang sangat besar bagi pendapatan masyarakat dan mampu menjadi sumber mata pencaharian bagi masyarakat.

\section{PENUTUP}

Simpulan

Analisis tekno ekonomi pemanfaatan limbah ikan tuna sirip kuning layak dibuat menjadi pakan ikan organik. Hasil pembuatan pakan menghasilkan keuntungan yang sangat besar yang dapat menjadi sumber mata pencaharian alternatif bagi masyarakat, sekaligus dapat menjadikan ekosistem dan sumberdaya tetap lestari dapat mengoptimalkan pemanfaatannya untuk peningkatan kesejahteraan masyarakat.

\section{Saran}

Pemerintah Kota Jayapura dapat merekomendasikan strategi dan model pengelolaan perikanan tuna sirip kuning yang mencerminkan aspek menyeluruh dan terintegrasi antar sektor dalam mendukung pembangunan daerah Kota Jayapura yang efisien dan berkelanjutan serta peningkatan kesejahteraan masyarakat. Pengelolaan limbah ikan tuna sirip kuning dapat dijadikan mata pencaharian alternatif dan mengembangkan Usaha Mikro, Kecil dan Menengah (UMKM) yang berbasis ekonomi biru.

\section{Ucapan Terimakasih}

Penulis mengucapkan terimakasih kepada Ketua Lembaga Penelitian dan Pengabdian Masyarakat (LPPM) Universitas Cenderawasih yang telah mendanai penelitian ini pada Skema Hibah Penelitian Doktor Tahun Anggaran 2020. 


\section{REFERENSI}

Apu RL. 2017. Pemanfaatan limbah jeroan ikan cakalang (katsuwonus pelamis) sebagai bahan substitusi tepung ikan terhadap kinerja pertumbuhan pada ikan nila (Oreochromis niloticus). Tesis. Program Pascasarjana Universitas Hasanuddin.

[BPS] Badan Pusat Statistik Kota Jayapura. 2018. Kota Jayapura Dalam Angka 2017. Jayapura. BPS.

Dahuri R. 2004. Membangunan Kelautan dan Perikanan. Jakarta: Bening.

Danil M. 2013. Pengaruh pendapatan terhadap tingkat konsumsi pada Pegawai Negeri Sipil di Kantor Kabupaten Bireuen Aceh: Jurnal STIE Kebangsaan Bireuen. 4(7):10-25.

[DEKIN] Dewan Kelautan Indonesia. 2012. Kebijakan kelautan Indonesia buku I (buku I). Jakarta: Kementerian Kelautan dan Perikanan.

Edison dkk. 2015. Studi pembuatan pupuk organic padat dari limbah perikanan. Jurnal Jurusan Perikanan Universitas Riau.

Fahrizal A, Ratna. 2018. Analisa proksimat pellet berbahan limbah ikan PPI Klaligi Kota Sorong. Median volume. 10(3): 31-38.

Helmi E. 2012. Strategi Adaptasi Nelayan Terhadap Perubahan Ekologis. Conaplin Jurnal Makara, Sosial Humaniora, 16(1): 68-78.

Imron M. 2003. Pengembangan ekonomi nelayan dan sistem sosial budaya. Jakarta: Penerbit PT. Gramedia.

Kusumastanto T. 2012. Development of marine and fishery based on industrialization policy in blue economy approach. Makalah Seminar Nasional Kerjasama Kementerian Kelautan Republik Indonesia dan PKSPL-IPB. Tidak Dipublikasikan

Manurung LU, Sukendi, Windarti, E. Sumiarsih. 2014. Pengaruh Aktifitas KJA pada Kebiasaan Makan Ikan Kapiek (Puntius schawanefeldi) dan Ekonomi Nelayan Tradisional pada Waduk Koto Panjang Propinsi Riau. Jurnal Berkala Perikanan Terubuk. 42(1): 80-91.

Pauli G. 2010. The blue economy 10 years 100 innovations 100 million jobs inspired by nature. Taos, New Mexico: Paradigm Publications.

Pauly D, Watson R. 2005. Background and interpretation of the Marine Trophic Index as a measure of biodiversity. Phil.Trans.R.Soc.B360.(In the press.) (doi:10.1098/rstb. 2004.1597).

Pratama R, Manurung R. 2010. Teori Ekonomi Mikro (suatu pengantar) Edisi Keempat. Jakarta: BPFEUI.

Sukirno S. 2006. Ekonomi pembangunan: proses, masalah dan dasar kebijakan. Jakarta: Prenada Media Group

Undang-Undang Nomor 45 Tahun 2009 Tentang Perikanan 